\title{
CULTIVATING PRE-SERVICE TEACHERS' CLASSROOM MANAGEMENT SKILLS THROUGH TEACHING PRACTICUM: A REFLECTIVE PRACTICE
}

\author{
Debora Tri Ragawanti \\ (dera03@yahoo.com) \\ Universitas Kristen Satya Wacana \\ Jln. Diponegoro 52-60, Salatiga, Jawa Tengah
}

\begin{abstract}
Classroom management is commonly believed to be the key to the success of an instruction. Many student teachers, however, might find it very challenging to handle their classrooms. It is, therefore, necessary to advance their professional practice in the context of a real classroom such as through teaching practicum and reflective practice. This study is aimed at identifying classroom management problems of student-teachers as revealed in their reflective journal entries and to demonstrate how such journal can help them develop their classroom management skills. The participants were 10 student-teachers of the English Department, Satya Wacana Christian University, Salatiga, Central Java, who underwent their teaching practicum at SMP 2 Salatiga. Through the participants' journals, it was found that the problems lie in managing critical moments, activity, techniques, grouping and seating, authority, tools, and working with people. Further in this study, both pre- and in-service tertiary teachers, curriculum designers, and policy makers will be taken to deeply examine how reflective practice can help cultivate the pre-service's classroom management skills and to consider the implication for pedagogical practices and innovations in curriculum development.
\end{abstract}

Keywords: classroom management, reflective journal, and pre-service teachers

DOI: http://dx.doi.org/10.15639/teflinjournal.v26i1/117-128 
As a lecturer at the English Teacher Education Program, I regularly supervise students doing their teaching practicum in our neighboring high schools. During the supervision, they often share their teaching experiences. I remember some of them told me these problems, "Ma'am, did you happen to notice the students at the very back row? He was very quiet and did not want to mingle with other students. I am confused what to do with him." Another story is like this, "Ohhh, my teaching today was terrible Ma'am. I even could not finish the main activity." As a response, I shared similar experience of mine or discussed the problem together. However, at that time, I failed to realize that those kinds of experience can be problematical and even critical for many student-teachers until I read the paper of Arends (2012); Goh and Matthews (2011); and Monroe, Blackwell, and Pepper (2010). Those journal articles mentioned that such complexities in establishing and managing a classroom have been reported by a lot of pre-service student-teachers to be the most difficult and worrisome aspect of their first years of teaching. This situation has motivated me to explore more about it and to help them improve their skills in managing a classroom since it is considered "the key to the whole success of a course" (Scrivener, 2005, p.79).

Scrivener (2005) classified teacher's classroom management into six areas. The first one is grouping and seating. It may consist of teacher's action in forming groupings (singles, pairs, groups, mingle, plenary), reforming class as a whole group after activities, arranging and rearranging seating, and in deciding where they stand or sit. The second one is managing activities and giving instructions. It varies from preparing and sequencing activities, setting up activities, running a single classroom activities or tasks, monitoring activities, timing activities (and the lesson as a whole), until bringing activities to an end. The third area deals with managing authority. It involves gathering and holding attention, deciding who does what, establishing and giving up authority as appropriate, and getting someone to do something.

The fourth area is managing critical moments. It concerns unexpected problems and maintaining appropriate discipline. Harmer (2001) gives more specific examples of problem behavior like disruptive talking, inaudible responses, sleeping in class, tardiness and poor attendance, failure to do homework, cheating in test and unwillingness to speak in the target language. The fifth area is managing tools and techniques. Tools contend with variety of teaching aids used to explain language meaning and construction, or to engage students in a topic, such as, the overhead projectors, the board, bits and pieces 
(photography of our family, letters, or even a pet), realia, language cards, Cuisenaire rods, the language laboratory (VCD, microphone, TV), and the internet. As for techniques, Scrivener (2005) defined it as teacher's techniques of teaching such as using gestures and facial expressions to help make instructions and explanations clearer, speaking clearly at an appropriate volume and speed, using silence, grading complexity of language, and grading quantity of language. The last area is working with people. It deals with eliciting/drawing out information, language, ideas, honest feedback, etc. from students; using intuition to guess/judge what students are feeling, spreading attention clearly and appropriately, and really listening to students.

In response to the beginning teachers' problems in managing a classroom and to the importance of classroom management, Monroe et al. suggested that teacher preparation programs and their school partners work collaboratively to provide pre-service teachers with knowledge of classroom management and opportunities for guided practice, and for implementing both preventive and behavior management strategies (2010). The opportunity can be obtained through teaching practicum.

Teaching practicum, often used interchangeably with teaching practice, is aimed at providing opportunities to the trainee [in this case the pre-service teacher] to build up and to advance her/his professional practice in the context of a real classroom, usually under some kinds of guidance or supervision (Wallace, 1991).

With regard to teaching practicum as a professional preparation, Wallace (ibid) categorized it into three models: the craft model, the applied science model, and the reflective model. The first refers to studying with the 'master'. It means that the novice trainee learns by doing what the expert practitioner has told her/him to do and imitating what the expert has showed him to do. The second refers to applying science knowledge. In this case, the expert shows the finding of science knowledge or experiment to the trainee. The trainee then will decide how to apply it in their teaching. The third model, reflective model, comes from the idea that a teacher should have had both received knowledge (the vocabulary of the subject, research findings, skills) and experiential knowledge (professional ongoing experience) because those knowledge will underlie the practice of everyday teaching. Most importantly, reflection is done as a response to their teaching. This reflection, is believed to facilitate the teacher to gain their professional competence. 
My own opinion is in line with the reflective model for a professional preparation because in that kind of preparation, like teaching practicum, an individual teacher is encouraged to observe, to think over and to examine their teaching, to connect the knowledge obtained to the on-going teaching practice. By so doing, the teacher will be more alert and thoughtful on what happens to her/his teaching and possibly find the solution of and/ or strategy to cope with the teaching problems through examining the patterns of problems and practice appeared. In this way, reflective model can pave the way for an individual teacher to develop his/her professional growth.

Reflective approach in English teaching and learning is applied "when teachers and student-teachers collect data about their teaching, to examine their attitudes, beliefs, assumptions, and teaching practices, and use the information obtained as a basis for critical reflection about teaching" (Richards \& Lockhart, 1996 , p. 1). This clearly entails a series of process, starting from gathering data on teaching episodes, examining some concerns on teaching and learning, and reflecting on them for better practice. Ghaye (2011) urged that such a process is believed to be valuable because it can develop new insights and understandings that can be helpful for our teaching improvement .

To accommodate such reflective thinking above, reflective journal has been widely promoted. As defined by Richards and Lockhart (1996), reflective journal is "a teacher's or a student teacher's written response to teaching events" (p. 7). Richards and Farrell (2005, p. 68) define it more elaborately as "an ongoing written account of observation, reflection, and other thoughts about teaching". The definition clearly tells us that reflective journal is not only a written document but also recollection, examination, evaluation, and thoughts on some aspects of teaching. Such a journal can work well for facilitating an individual teacher to question, explore, and analyze his/her way of teaching such as his beliefs and teaching practices. Furthermore, it can also be used to monitor teaching and to interact with peers and supervisors. In this case, the peer or supervisor can read the journal and give suggestions and/or a way out to the problems experienced in teaching.

Due to such benefits of reflective journal for teacher's professionalism growth, many studies have been conducted to explore the use of refective journals in the teaching and learning process. Clarke (2004) analyzed the reflective journal entries of student-teachers doing an internship program in one university in Sydney and categorized the entries into Dietz model of Professional learning (exploration, organization, connection, and reflection). 
The results showed that in each phase, the student-teachers were concerned with different problems. In the exploration and organization phase, their concerns include how to plan a lesson, handle administrative things, and manage the classroom while in the connection and reflection phase, and they are concerned with their teaching. In addition, Subramanian (1997) conducted a study in a teacher's college in Malaysia investigating the teacher trainees' reflection focus in their reflective journal entries. The results demonstrated that one of their reflection focuses deal with teaching objectives, teaching techniques and method, activity and classroom management. Another study in Malaysia done by Goh and Matthews (2011) also investigated the studentteachers' concerns during their teaching practice. Through their reflective journals, problems in classroom management, institutional and personal adjustment, classroom teaching, and student learning were identified.

It is evident from the journal entries used in the above previous studies that classroom management has become one of the main concerns for many pre-service teachers. However, a study solely focused on how reflectice journal can reveal the pre-service teacher's problems in managing a classroom seems scarcely to be found. This study, therefore, attempts to look into the preservice teachers' problems in managing a classroom as stated in their reflective journal entries and how such reflective journal practice can help build their classroom management skills.

\section{METHOD}

The subjects in this study were ten (10) student teachers who enrolled in the final year of their bachelor degree program at the Faculty of English Language and Literature, majoring in English Language Teaching, at Satya Wacana Christian University, Salatiga, Indonesia.

The context of the study was at SMPN 2 (State Junior High School 2), Salatiga, Indonesia, where the subjects did their teaching practicum for three months and underwent a six-time-teaching for grade seven, eight, and nine spread over the three-month period. During their teaching practicum, they were under the supervision of three (3) mentor-teachers from the school and a teacher-supervisor from the university.

The source of data was the student-teachers' journals. Throughout their teaching practicum, they were required to write a narrative journal every time 
they finish teaching. Therefore, there were sixty (60) journal entries to be analyzed.

The data were collected through the following steps. First, the subjects were required to write a journal and to submit it soon after they finished teaching. Secondly, after all journals were collected, the data were analyzed. It was done by scrutinizing problems related to classroom management which appeared in the journal and then classifying them into the areas of classroom management. The third step is analyzing student-teachers' reflection to see how they dealt with their classroom management problems and how their reflection could help them improve their classroom management skills.

\section{FINDINGS AND DISCUSSION}

This section discusses the findings to answer the research questions on the student-teachers' classroom management problems revealed in their reflective journal entries and how the reflective journal practice help build their classroom management skills.

\section{The Student-Teachers' Classroom Management Problems Revealed in Their Reflective Journal Entries}

Figure 1 illustrates the student-teachers' problems in managing a classroom within seven areas of classroom management. i.e. critical moment, techniques, activity, grouping ad seating, authority, tools and working with people.

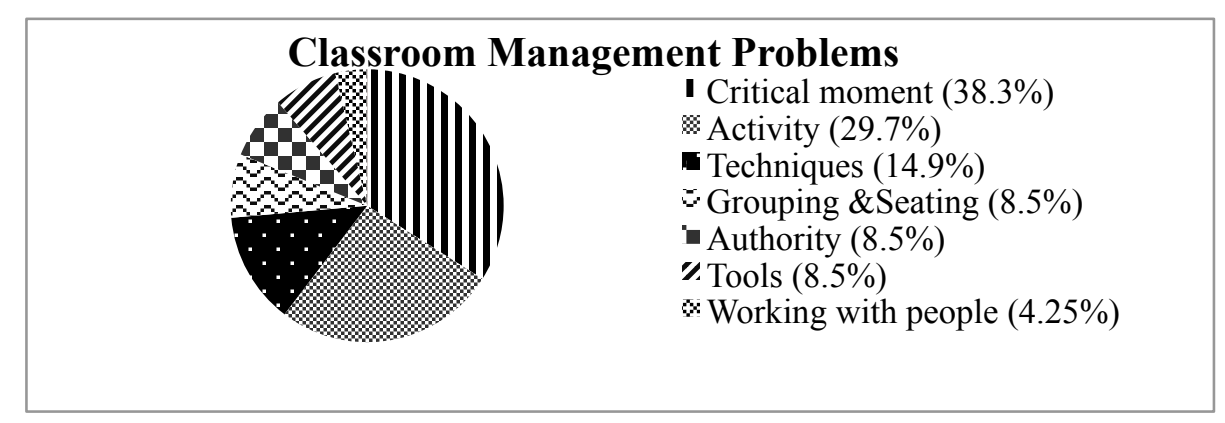

Figure 1. Student-Teachers' Classroom Management Problems Revealed in Their Journal Entries 
The finding reveals that the student teachers' problems in managing a classroom based on the order of occurrence is managing critical moments $(38,3 \%)$, activity (29,7\%), techniques (14,9\%), grouping and seating $(8,5 \%)$, authority $(8,5 \%)$, tools $(8,5 \%)$, and working with people $(4,25 \%)$.

From the participants' journal entries, it is revealed that the problems frequently occurred in managing critical moments are handling student's noise and silence. In managing activities, the most difficulties took place in timing activities, making activities run smoothly, and developing classroom activities that meet certain expectation such as enjoyable and fun. In terms of techniques, the hard things to manage were using language and speech rate when explaining materials. In grouping and seating, the obstacle was in technicality of grouping. As for performing an authority, they commonly got confused to decide what to do when the students were doing class activities, and when the students did not want to do their instructions. The next problem is managing tools. For example, the laptop and the video player did not work well and the students could not read their writing on the board because of their unclear writing. As for problems in the area of working with people, the use of intuition was the main challenge for them. It was not easy for them to decide what to do when facing unpredictable situations.

\section{How Reflective Journals Help the Students-Teachers Improve Their Classroom Management Skills}

In attempts to look into the reflective practice on classroom management problems, we can refer to the scheme proposed by Scrivener (2005) and Ghaye (2011). The scheme consists of three stages. The first is to examine classroom events. The second is to identify the teacher's concerns or problems related to managing a classroom. The third is to see how the teacher may come up with strategies to cope with the problems until finally choose the best option for better teaching. A particular improvement can be seen after examining the series of process. By refering to the scheme, this section is aimed at illustrating how reflective practice can help the student-teachers improve their classroom management skills. For the sake of efficiency, only the top three of the findings will be discussed. The journal entries used as the supporting evidence were quoted verbatim. 


\section{The Student-Teachers' Problems in Managing Critical Moments}

As revealed in the findings, one of the problems in this area is handling student's noise. From the reflective journals collected, we can see how participant 2, for example, looked back at her teaching and identified problems with noisy students. As stated in journal entry 1, she found the students boisterous when she explained the rule of the game. It happened again in her next lesson even though she had given engaging materials.

...They were getting noisy, when I explained the rules of the game. I warned noisy students to be quiet... [sic] (participant 2, journal entry 1).

I found out that the class is noisy. Some students kept busy with their own business even though I had attractive materials for them. I didn't remember how many times I reminded certain students to pay attention and listen to their friends' performance, but those certain students kept busy until the class almost over [sic] (participant 2, journal entry 3).

In response to the problems, the participant told the students to be silent. This strategy seemed to be done many times but failed to make them quiet. After a number of meetings, the issue seemed to be resolved as reflected in the following excerpt of her reflective journal.

.... Looking at how I have managed the classroom, I learn about to be patient and calm to deal with various kinds of students. Specifically, I have understood what I should do in dealing with passive and active students and noisy classroom as well. Besides, personally it gives me maturity to detain my temper in dealing the annoying and noisy students. [sic] (participant 2, journal entry 6).

Quite surprisingly, this participant chose to be calm and patient in handling the noise, a strategy which was totally different from the previous one and turned out to be sucessful.

Practically, dealing with students who do not want to stop talking and to listen to the teacher is not an easy thing and said to be one of the frequent and worrisome problems in managing a classroom (Sakui, 2007; Goh \& Matthews, 2011). However, from the reflective journal entries above, we can see how this participant succed in handling the problem. As evident, she keeps on reflecting on her teaching to examine and evaluate her ways to manage noisy students by warning, and ordering them to be quiet until ultimately she realizes that 
keeping herself calm and patient work better than the previous ways. In fact, this strategy is successful. In conclusion, through such a reflection this participant gain improvement in managing a classroom.

\section{The Student-Teachers' Problems in Managing Activities}

Another concern in managing classroom activities frequently found in the journals is to develop classroom activities into fun and enjoyable activities, which coincides with the expectation that most learners have regarding their classes. A study conducted by Liando on 126 English Department students in one university in Manado (2010), for example, found that $96 \%$ of the participants expected their teachers to be able to make the course interesting. The participants of the study, however, found this aspect to be challenging as revealed in the following excerpts from one participant.

I found a little confusion to arrange the lesson plan, to make a cool and interesting or fun activities or ways to explain simple present tense... [sic] (participant 4 , journal entry 1 ).

Teaching structure actually a little bit hard for me; because I am not that creative to make many fun class activities to help students understand the material easily [sic] (participant 4 , journal entry 2 ).

The above reflection demonstrates the participant's perplexed feelings in preparing a lesson plan, especially in designing fun activities. She really wanted to create fun classroom activities to make the students understand the material easily but she did not think she could. Yet she managed to make a series of efforts to design fun classroom activities as illustrated from the summary of her journal entries in the following paragraph.

Firstly, when she taught descriptive text, as stated in her journal entry 2, she tried to grab her students' attention by discussing an Indonesian famous comedian, Sule. In her opinion, it worked well but unfortunately, she did not use pictures to visualize the figure. From this reflection, therefore, she thought that improvement was needed. Subsequently, in her next teaching, as reflected in journal entry 3 , she came up with the picture of someone that the students know well. She found it more attractive to the students especially because this was closely related to their life or environment. She continued developing her teaching creativity by making use of power point. In her journal entry 4 , she re- 
flected on the use of power point and found it helpful for the teaching and learning process. Only that she learned how the picture and animation in the power point could distract the students' attention. Furthermore, as a last effort for making the lesson enjoyable, she provided a video about likes and dislikes in English. As revealed in her journal entry 5, she learned good things from using videos such as promoting fun learning and enhancing students' participation and speaking skill.

In short, from the reflective practice of Participant 4 , we can see how she enhances the way she manages classroom activities. It is evident that after reflecting on her weakness in desingning engaging activites, this participant tried to find and explore an interesting topic, such as, an Indonesian comedian. After that, she, again, examined the shortcoming of the activity and tried to make it more engaging, that is, by using pictures. She did the reflection and improvement repeatedly until she finally learns that pictures, power point, video and things closely related to the students can be used to create fun learning activities. In this case, her ability in managing classroom activities is developed.

\section{The Student-Teachers' Problems in Managing Teaching Techniques}

The common classroom management problems in teaching techniques deal with language use and speech rate. This finding is indeed pivotal to see since speech rate has become a significant part of teacher talk that contributes to intelligibility (Hall, 2002). Therefore, it will be useful to look at how a student-teacher reflect on his problem with rate of speech until he finally gains a better skill in dealing with the classroom management problem:

Another thing I need to improve is on the way I communicate because I think sometimes I speak too fast so that the students maybe do not really understand with my explanation (Participant 5, journal entry 1 ).

From the reflective journal, Participant 5 realized that he had a tendency to speak fast. Furthermore, he was concerned that his fast rate of speech might make his explanation unclear. The participant's supposition was in line with what Ragawanti (2007) found through her research on a group of EFL learners in Indonesia, that teacher's rapid explanation in a teacher talk can make students confused and difficult to internalize the input. This concern then made 
the participant reflected on his teaching, with regard to the issue, a number of times.

However, there is still some basic problems that I need to pay attention on, such as, the communication skills, ... still, I need to improve on the way I communicate because I think I still speak too fast so that the students maybe do not really understand with my explanation [sic] (Participant 5, journal entry 4).

Besides, I also felt that I could communicate and interact with the class better..... [sic] (Participant 5, journal entry 5).

As stated in journal entry 4, he examined his good progress on this but his mentor teacher still found that he sometimes spoke too fast when explaining. To follow up his reflection, he tried to improve his speech rate, and as seen in journal entry 5 , he at last found his skill to manage his speech rate improved.

\section{CONCLUSIONS AND SUGGESTIONS}

The findings and discussion in the previous section show that managing a classroom can put some challenges to the student-teachers which, in particular, concern handling students' disruptive behaviors, classroom activities, teaching techniques, and tools. As the implication for pedagogical practices, the teachers and/or syllabus designers need to give more knowledge about and practices in managing a classroom. The other point revealed from the finding is the effectiveness of reflective journal practice in helping the student-teachers examine the episodes of their teaching, find the pattern of the problems, and decide what to do to cope with the problems. By so doing the student-teachers' skills in managing a classroom get improved. The proposition for pedagogical practices is for teachers and/or syllabus designers to put emphasis on reflective practice in as many courses as possible. Accordingly, many more aspects or problems in teaching and learning can be found or improved.

\section{REFERENCES}

Arends, R. (2012). Learning to teach. New York: McGraw Hill.

Clarke, M. (2004). Reflection: Jounals and reflective questions: A strategy for professional learning. Australian Journal of Teacher Education, 29(2), 113. 
Ghaye, T. (2011). Teaching and learning through reflective practice: A practical guide for positive action. Oxon: Routledge.

Goh, P. S., \& Matthews, B. (2011). Listening to the concerns of student teachers in Malaysia during teaching practice. The Australian Journal of Teacher Education, 36(3), 92-103.

Hall, J. K. 2002. Methods for teaching foreign languages. New Jersey: Merril Prentice Hall.

Harmer, J. 2001. The practice of English language teaching. Oxford: Oxford University Press.

Liando, N. V. F. Students' vs. teachers' perspectives on best teacher characteristics in EFL classrooms. TEFLIN Journal, 21(2),118-136.

Monroe, A. E., Blackwell, S. E., \& Pepper, S. K. (2010). Strengthening professional development partnerships while bridging classroom management instruction and practice. The Professional Educator, 34(2). Retrieved from http://files.eric.ed.gov/fulltext/EJ988200.pdf.

Ragawanti, D.T. Constructions and obstructions of teacher explanation to students' learning: Perspectives of STIBA Satya Wacana Students. TEFLIN Journal, 18(1), 1-98.

Richards, J. C., \& Farrell, T. (2005). Professional development for language teachers. Cambridge: Cambridge University Press.

Richards, J. C., \& Lockhart, C. (1996). Reflective teaching in second language classrooms. Cambridge: Cambridge University Press.

Sakui, K. (2007). Classroom management in Japanese EFL classrooms. JALT Journal, 29(1), 41-58.

Scrivener, J. (2012). Classroom management techniques. Cambridge: Cambridge University Press.

Scrivener, J. (2005). Learning teaching. Oxford: Macmillan Education.

Subramanian, M. (1997). Journal writing as a tool for teacher trainees' reflection on teaching (Unpublished Master's Thesis, University of Massey, NZ.).

Wallace, M. J. (1991). Training foreign language teachers. Cambridge: Cambridge University Press. 